\title{
Fucoidan Inhibits the Proliferation of Leiomyoma Cells and Decreases Extracellular Matrix-Associated Protein Expression
}

\author{
Hsin-Yuan Chen ${ }^{\mathrm{a}}$ Tsui-Chin Huang ${ }^{\mathrm{b}, \mathrm{c}}$ Li-Chun Lin ${ }^{\mathrm{b}} \quad$ Tzong-Ming Shieh ${ }^{\mathrm{d}}$ \\ Chi-Hao Wu ${ }^{e}$ Kai-Lee Wang ${ }^{f}$ Yong-Han Hong ${ }^{g}$ Shih-Min Hsia ${ }^{a, h, i, j}$
}

aSchool of Nutrition and Health Sciences, College of Nutrition, Taipei Medical University, Taipei, bPhD Program for Cancer Biology and Drug Discovery, College of Medical Science and Technology, Taipei Medical University and Academia Sinica, Taipei, 'TMU Research Center of Cancer Translational Medicine, Taipei Medical University, Taipei, dDepartment of Dental Hygiene, College of Health Care, China Medical University, Taichung, eDepartment of Human Development and Family Studies, National Taiwan Normal University, Taipei, fDepartment of Nursing, Ching Kuo Institute of Managemnet and Health, Keelung City, 9Department of Nutrition, I-Shou University, Kaohsiung City, hGraduate Institute of Metabolism and Obesity Sciences, College of Nutrition, Taipei Medical University, Taipei, 'School of Food and Safety, Taipei Medical University, Taipei, jNutrition Research Center, Taipei Medical University Hospital, Taipei, Taiwan

\section{Key Words}

Uterine leiomyoma • Fucoida • Transforming growth factor beta • Extracellular matrix • ELT-3LUC • Xenograft model

\begin{abstract}
Background/Aims: Uterine leiomyomas (ULs) are benign uterine tumors, and the most notable pathophysiologic feature of ULs is excessive accumulation of extracellular matrix (ECM). Fucoidan is a polysaccharide extracted from brown seaweeds that has a wide range of pharmacological properties, including anti-fibrotic effects. We aimed to study the effect of fucoidan on the growth of ULs activated by transforming growth factor beta (TGF $\beta$ ). Methods: We used ELT-3 (Eker rat leiomyoma tumor-derived cells) and HUtSMC (human uterine smooth muscle cells) as in vitro models. Cell viability was determined by the MTT assay. Cell colony formation was stained using crystal violet. The side population, cell cycle and apoptosis were analyzed using flow cytometry. Protein expression was assayed by western blot analysis. We also conducted in vivo experiments to confirm the inhibitory effects of fucoidan in nude mouse xenograft models. Tumor tissues were assayed by immunohistochemistry analysis. Results: In our study, fucoidan caused a 50\% growth inhibition using a dose of $0.5 \mathrm{mg} / \mathrm{ml}$ and decreased the stem cell activity after $48 \mathrm{~h}$. In addition, fucoidan induced sub-G1 cell cycle arrest and apoptosis. Fucoidan down-regulated fibronectin, vimentin, $\alpha$-SMA and the COL1A1 protein

\begin{tabular}{ll}
\hline Shih-Min Hsia & School of Nutrition and Health Sciences, Taipei Medical University, \\
& 250, Wu-Hsing Street, Taipei 11031 (Taiwan) \\
& Tel. +8862 7361661 6558, E-Mail bryanhsia@tmu.edu.tw
\end{tabular}
\end{abstract}


levels in TGF $\beta 3$-induced ELT-3 cells. In the cellular mechanism, fucoidan abrogated TGF $\beta 3$ induced levels of $p$-Smad 2 and $p$-ERK1/2, as well as $\beta$-catenin translocation into the nucleus. Furthermore, fucoidan suppressed xenograft tumor growth in vivo. Conclusion: Fucoidan displays anti-proliferation and anti-fibrotic effects and exerts protective effects against ULS development.

(C) 2018 The Author(s)

Published by S. Karger AG, Basel

\section{Introduction}

Benign uterine leiomyomas (ULs), also known as myomas or fibroids, have received attention as a female disease. ULs are the most common tumor of the uterus, affecting one in fourth women of reproductive age [1], and occur in over 77\% of women in the United States [2]. Most women with ULs are asymptomatic; however, $20 \%$ of ULs patients usually suffer from a reduced quality of life with symptoms such as abnormal uterine bleeding, pelvic pain, frequent urination, and infertility $[3,4]$. Although the etiology remains unclear, genetic factors, cytokines, growth factors, steroid hormones (estrogens and progestogens) and/or their receptors, and excessive production of extracellular matrix (ECM) plays pivotal roles in the development of ULs $[3,5]$. In addition, hypoxia can trigger stem cell proliferation during the initiation of fibrosis, leading to fibroids [6].

Under normal physiological conditions, the degradation of the ECM is precisely regulated [7]. However, when the cells do not respond correctly to the usual signals, pathological fibrosis occurs [8]. The ECM components have attracted increased attention regarding ULs growth, which include fibronectin, collagens, and proteoglycans (biglycan and fibromodulin) $[9,10]$. Transforming growth factor beta (TGF $\beta$ ) is one of the most important cytokines underlying the accumulation of ECM constituents in ULs, especially TGF $\beta 3$ [11].

Some patients suffer from leiomyoma, apart from hysterectomy, and most therapeutic treatments only provide temporary effectiveness [12]. Postoperative complications can be relieve by using conventional medical treatment, but the cost related to ULs is considerable. To ameliorate the influence of conventional medical treatment, many studies have demonstrated the chemopreventive and anticancer potential of dietary polyphenols, such as resveratrol [13], epigallocatechin gallate (EGCG) [14], green tea extract [15], and strawberry extract [16]. Therefore, the selection of natural extracts as adjuvants for chemotherapy is important.

Fucoidan is a complex series of sulfated polysaccharides found in the cell-wall matrix of brown seaweeds that contain high amounts of L-fucose and sulfate ester groups $[17,18]$. The structure of fucoidan and its composition strongly depend on the extraction source (the type of algae) and the method of extraction, thereby affecting its effectiveness. Fucoidan extracted from different species has varied biological activities, including anti-coagulant [19], antioxidant [20], immunomodulatory [21], anti-inflammatory [22], antibacterial activity [23], and anti-obesity [24, 25] properties. Alternatively, different processing methods are also important factors that influence the molecular conformational changes. Purified fucoidan preparation (PFP) has a higher cytotoxic effect due to the higher sulfate content compared with crude fucoidan preparation (CFP) [26]. Lowering the molecular weights (Mw) of fucoidan enhanced the anti-tumor activities by improving the binding properties of sulfate groups [27]. Furthermore, low-molecular-weight fucoidan (LMWF) prepared by gammairradiation not only avoided the removal of sulfate groups but also increased the cytotoxicity against cell transformation in cancer [28].

Recent in vivo and in vitro studies indicated that fucoidan is a potent anti-tumor agent in cancer cells (e.g., colon, liver, bladder and breast cancer) [29-35]. However, no study has reported the relationship of ULs and fucoidan. Therefore, in the present study, we aimed to investigate the inhibitory effects of fucoidan on ULs growth both in vitro and in vivo. 


\section{Cellular Physiology Cell Physiol Biochem 2018;49:1970-1986 \begin{tabular}{ll|l} 
and Biochemistry Published online: 21 September, 2018 & $\begin{array}{l}\text { (c) } 2018 \text { The Author(s). Published by S. Karger AG, Basel } \\
\text { www.karger.com/cpb }\end{array}$ \\
\hline
\end{tabular}

\section{Materials and Methods}

\section{Compliance with ethical standards}

All animal experiments complied with the ARRIVE guidelines and were carried out in accordance with the National Institutes of Health guide for the care and use of Laboratory animals (NIH Publications No. 8023, revised 1978) and the guidelines of the Taipei Medical University.

\section{Cell culture}

The Eker rat-derived uterine leiomyoma cells (ELT-3) were kindly provided by Dr. Lin-Hung Wei (Department of Oncology, National Taiwan University Hospital, Taipei, Taiwan). Eker rat-derived uterine leiomyoma cells transfected with luciferase reporter genes (ELT-3-LUC) were established in our laboratory previously. Primary human uterine smooth muscle cells (HUtSMC) were purchased from PromoCell (Heidelberg, Germany). ELT-3, ELT-3-LUC and HUtSMC cells were cultured in Dulbecco's Modified Eagle Medium/Nutrient Mixture F-12 (DMEM/F12, CAISSON Labs, UT, USA). Both cell lines were maintained in a medium containing 10\% Fetal bovine serum (FBS) and 1\% antibiotics (10, 000 units $/ \mathrm{ml}$ penicillin, 10, 000 $\mu \mathrm{g} / \mathrm{ml}$ streptomycin, and $25 \mu \mathrm{g} / \mathrm{ml}$ amphotericin with $8.5 \mathrm{~g} / \mathrm{L} \mathrm{NaCl}$ ) and incubated at $37^{\circ} \mathrm{C}$ with $5 \% \mathrm{CO}_{2}$.

\section{Reagents and antibodies}

0.05\% trypsin-ethylenediaminetetraacetic acid (EDTA, $1 \times$ ), and antibiotic-antimycotic solution $(100 \times)$ were purchased from CAISSON Labs (UT, USA). FBS, trypan blue, a bicinchoninic acid (BCA) protein assay kit, an electrochemiluminescence (ECL) immunoassay were purchased from Thermo Fisher Scientific (UT, USA). Bovine serum albumin (BSA) was purchased from BioShop (Burlington, Canada). Protease and phosphatase inhibitor cocktail tablets were purchased from Roche (Basel, Switzerland). Sodium bicarbonate, 3-(4, 5-dimethylthiazol-2-yl)-2, 5-diphenyltetrazolium bromide (MTT), dimethyl sulfoxide (DMSO), Hoechst 33342, and verapamil were purchased from Sigma-Aldrich (MO, USA). VivoGlo ${ }^{\mathrm{TM}}$ Luciferin (in vivo Grade) was purchased from Promega (WI, USA). Matrigel® Basement Membrane Matrix was purchased from Corning (NY, USA). Zoletil ${ }^{\circledR} 50$ was purchased from Virbac (Carros, France). Rompun ${ }^{\circledR}$ 20 (xylazine hydrochloride) was purchased from Bayer (Leverkusen, Germany). The following antibodies were used in this study (Table 1): anti-Bax, anti-Bcl-2, anti-p-Smad2, anti-Smad2/3, anti-p-ERK1/2, antiERK1/2, Histone H3, and anti-proliferating cell nuclear antigen (PCNA) were purchased from Cell Signal Technology (MA, USA); anti-vimentin, anti- $\alpha$-SMA, anti-collagen type I alpha 1 (COL1A1), anti- $\beta$-catenin, and anti- $\beta$-actin were purchased from GeneTex (CA, USA); anti-cyclin-D1, anti-cyclin-dependent kinase 4 (CDK4), anti-fibronectin, anti-T $\beta$ R2, and goat anti-rabbit/mouse antibody IgG were purchased from Abcam (Cambridge, UK).

\section{Preparation of fucoidan and TGF 33}

The oligo-fucoidan powder from Laminaria japonica was kindly provided by Hi-Q Marine Biotech International Ltd (Taipei, Taiwan). A stock solution of $8 \mathrm{mg} / \mathrm{ml}$ was prepared in double-distilled $\mathrm{H}_{2} \mathrm{O}$ $\left(\mathrm{ddH}_{2} \mathrm{O}\right)$ and filtered using $0.22 \mu \mathrm{m}$ sterile filters (Merck Millipore, MA, USA) and then stored at $4^{\circ} \mathrm{C}$ until use. For in vitro experiments, the final concentrations of fucoidan were prepared by diluting the stock with the cell culture medium. In addition, 50 $\mathrm{mg} / \mathrm{kg}$ fucoidan was also prepared in $\mathrm{ddH}_{2} \mathrm{O}$ and

Table 1. List of antibodies used in this study. WB: western blotting; IHC: immunohistochemistry; HRP: horseradish peroxidase

\begin{tabular}{llll}
\hline Antibody & Source (Catalogue No.) & Application & Dilutions \\
\hline Primary antibody & Cell Signaling (\#2772) & WB & $1: 1000$ \\
anti-Bax & Cell Signaling (\#2870) & WB & $1: 1000$ \\
anti-Bcl-2 & Cell Signaling (\#3104) & WB & $1: 1000$ \\
anti-p-Smad2 & Cell Signaling (\#5678) & WB & $1: 1000$ \\
anti-Smad2/3 & Cell Signaling (\#9101) & WB & $1: 1000$ \\
anti-Phospho-p44/42 MAPK & Cell Signaling (\#9102) & WB & $1: 1000$ \\
anti-p44/42 MAPK (Erk1/2) & Cell Signaling (\#9715) & WB & $1: 10000$ \\
anti-Histone H3 & Cell Signaling (\#13110) & IHC & $1: 1000$ \\
anti-PCNA & Cell Signaling (\#8480) & WB & $1: 1000$ \\
anti- $\beta$-catenin & GeneTex (GTX100619) & WB & $1: 20000$ \\
anti-vimentin & GeneTex (GTX100034) & WB/ IHC & $1: 1000 / 1: 400$ \\
anti- $\alpha$-SMA & GeneTex (GTX112731) & WB & $1: 500$ \\
anti-COL1A1 & GeneTex (GTX109639) & WB & $1: 20000$ \\
anti- $\beta$-actin & Abcam (Ab86838) & WB & $1: 1000$ \\
anti-TRR2 & Abcam (Ab134175) & WB & $1: 10000$ \\
anti-cyclin-D1 & Abcam (Ab3112) & WB & $1: 1000$ \\
anti-CDK4 & Abcam (Ab2413) & WB/ IHC & $1: 1000 / 1: 200$ \\
anti-fibronectin & & & \\
Secondary antibody & Abcam (Ab205718) & WB & $1: 10000$ \\
Goat Anti-Rabbit IgG H\&L (HRP) & Abcam (Ab205719) & WB & $1: 10000$ \\
Goat Anti-Mouse IgG H\&L (HRP) & &
\end{tabular}




\section{Cellular Physiology Cell Physiol Biochem 2018;49:1970-1986

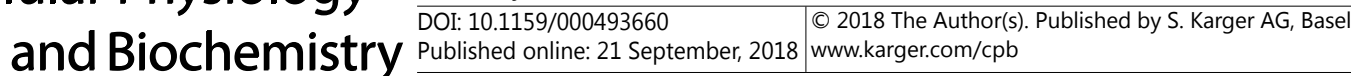 \\ Chen et al.: Anti-Proliferation Effect of Fucoidan in Leiomyoma}

used in in vivo experiments. The control groups were treated with a vehicle $\left(\mathrm{ddH}_{2} \mathrm{O}\right)$ both in vitro and in vivo. The recombinant human TGF $\beta 3$ was purchased from PeproTech (Rehovot, Israel). A stock solution of $100 \mu \mathrm{g} / \mathrm{ml}$ was prepared in $\mathrm{ddH}_{2} \mathrm{O}$ and then stored at $-20^{\circ} \mathrm{C}$ until use. The final concentrations of TGF $\beta 3$ were prepared by diluting the stock with the cell culture medium.

\section{Cell viability assay}

To evaluate the cytotoxic effect of fucoidan, we used an MTT assay. The ELT-3 cells were seeded in 96well plates $\left(2 \times 10^{3}\right.$ cells/well), cultured for $24 \mathrm{~h}$, and treated with various concentrations of fucoidan $(0,0.1$, $0.25,0.5,1 \mathrm{mg} / \mathrm{ml})$ in fresh medium containing $1 \%$ FBS. The MTT solution $(1 \mathrm{mg} / \mathrm{ml})$ was added directly to each well $(100 \mu \mathrm{L} /$ well $)$ for $4 \mathrm{~h}$. The absorbance was measured on the Epoch Microplate Spectrophotometer (BioTek, VT, USA) at $570 \mathrm{~nm}$, with a reference wavelength of $>630 \mathrm{~nm}$.

\section{Cell counting and colony formation assay}

ELT-3 cells were seeded onto 6-well plates and treated with $0.5 \mathrm{mg} / \mathrm{ml}$ fucoidan and $10 \mathrm{ng} / \mathrm{ml}$ TGFB3 in fresh medium containing 1\% FBS. After $96 \mathrm{~h}$, the cells were harvested in culture medium with $0.05 \%$ trypsin-EDTA solution. All of the cells and medium were collected at $4{ }^{\circ} \mathrm{C}$ and spun down at $500 \mathrm{~g}$ centrifugation for $5 \mathrm{~min}$. The cells were resuspended in $1 \mathrm{ml}$ of medium, and $10 \mu \mathrm{l}$ was used for cell counting in a hemocytometer with trypan blue staining to obtain the number of live and dead cells. In another hand, $0.5 \mathrm{mg} / \mathrm{ml}$ fucoidan and $10 \mathrm{ng} / \mathrm{ml} \mathrm{TGF} 33$ were added to the wells for $96 \mathrm{~h}$; the cells were then detached, reseeded onto a $10 \mathrm{~cm}^{2}$ dish at a density of $2 \times 10^{3}$ cells per dish, and cultured with fresh medium. Cells were incubated at $37^{\circ} \mathrm{C}$ under $5 \% \mathrm{CO}_{2}$ for 5 days to allow the colonies to form (defined as containing 50 or more cells). Colonies were fixed in methanol and stained with $0.01 \%$ crystal violet for 20 min at room temperature. After removing the dye by washing, the colonies were photographed and then dissolved in DMSO with shaking for $3 \mathrm{~h}$. Then, $0.1 \mathrm{ml}$ of destain solution was added into the 96 wells and the absorbance was measured on the Epoch Microplate Spectrophotometer at $570 \mathrm{~nm}$.

\section{Side population (SP) isolation}

To detect of the distribution of side population, ELT-3 cells were seeded at a density of $1 \times 10^{6}$ per dish and cultured for $24 \mathrm{~h}$. The medium was replaced with fresh medium containing $1 \%$ serum with various concentrations of fucoidan $(0,0.5$ and $1 \mathrm{mg} / \mathrm{ml})$. After $48 \mathrm{~h}$, the cells were dissociated with trypsin $(0.05 \%)$, centrifuged at $1,200 \mathrm{~g}$ for $5 \mathrm{~min}$ at $4^{\circ} \mathrm{C}$, and resuspended in $1 \mathrm{ml}$ of cold HBSS (Hanks' balanced salt solution) with $2 \%$ FBS. Hoechst $33342(5 \mu \mathrm{g} / \mathrm{ml})$ was then added to a density of $1 \times 10^{6}$ cells per tube. A parallel aliquot was stained with Hoechst 33342 dye in the presence of $50 \mu \mathrm{M}$ verapamil. After incubation for 120 150 minutes and protection from light, the cells were centrifuged at $1,200 \mathrm{~g}$ centrifugation for $5 \mathrm{~min}$ at $4^{\circ} \mathrm{C}$ and resuspended in $1 \mathrm{ml}$ of cold HBSS solution with 2\% FBS. Finally, stem cells were analyzed using a FACS flow sorter.

\section{Flow cytometry analysis for the cell cycle distribution and apoptosis}

To assess cell cycle progression, ELT-3 cells were seeded onto culture dishes and incubated for $24 \mathrm{~h}$ to allow for exponential growth. The cells were co-treated with $0.5 \mathrm{mg} / \mathrm{ml}$ fucoidan and $10 \mathrm{ng} / \mathrm{ml} \mathrm{TGF} \beta 3$ for $72 \mathrm{~h}$. All of the cells were collected, $9 \mathrm{ml}$ of $70 \%$ ethanol was added slowly, and the cells were stored at $-20^{\circ} \mathrm{C}$ for at least $2 \mathrm{~h}$. The cells were washed at least once with cold PBS and resuspended in 300-500 $\mu \mathrm{l}$ propidium iodide (PI)/Triton X-100 staining solution (2 mg DNAse-free RNAse A and $0.40 \mathrm{ml}$ of $500 \mu \mathrm{g} /$ $\mathrm{ml}$ PI was added to $10 \mathrm{ml}$ of $0.1 \%\left(\mathrm{v} / \mathrm{v}\right.$ ) Triton X-100 in PBS). The cells were incubated for $30 \mathrm{~min}$ at $20^{\circ} \mathrm{C}$. Fluorescence was measured with a FACSCalibur flow cytometer (BD, CA, USA) and cell cycle distribution analyzed using CellQuest and Modfit LT programs (BD, CA, USA). For the apoptosis analysis, a commercial fluorescein isothiocyanate (FITC) Annexin V Apoptosis Detection Kit I (BD, CA, USA) was used. The ELT-3 cells were seeded in culture dishes and co-treated with $0.5 \mathrm{mg} / \mathrm{ml}$ fucoidan and $10 \mathrm{ng} / \mathrm{ml} \mathrm{TGF \beta 3} \mathrm{for} 72 \mathrm{~h}$. Then, the cells were stained with Annexin V-FITC and PI, incubated for $15 \mathrm{~min}$ at room temperature and protected from light. Apoptosis was analyzed using a FACSCalibur flow cytometer, and the results were analyzed using CellQuest software. 


\section{Cellular Physiology Cell Physiol Biochem 2018;49:1970-1986 \begin{tabular}{ll|l} 
and Biochemistry Published online: 21 September, 2018 & $\begin{array}{l}\text { (c) } 2018 \text { The Author(s). Published by S. Karger AG, Basel } \\
\text { www.karger.com/cpb }\end{array}$ \\
\hline
\end{tabular}}

\section{Western blot analysis}

The lysates of tumor tissues were prepared in ice-cold lysis buffer containing a protease inhibitor cocktail. The proteins $(30 \mu \mathrm{g})$ were boiled for $5 \mathrm{~min}$, separated using $12 \%$ SDS-polyacrylamide gel electrophoresis (SDS-PAGE), and then transferred electrophoretically to Immobilon-P polyvinylidene fluoride (PVDF) membranes for 150-180 min at $280 \mathrm{~mA}$ and $250 \mathrm{~V}$. Then, the membranes were blocked with blocking buffer $\left(5 \%(\mathrm{w} / \mathrm{v}) \mathrm{BSA}\right.$ in $1 \mathrm{X}$ TBST for $1 \mathrm{~h}$ at $25^{\circ} \mathrm{C}$, and incubated for $8 \mathrm{~h}$ with primary antibodies (Table 1) at $4^{\circ} \mathrm{C}$. The next day, the membranes were washed three times for 10 min each with TBST buffer, incubated for $1 \mathrm{~h}$ in blocking buffer with horseradish peroxidase (HRP)-conjugated secondary antibodies, and washed with TBST buffer three times for 10 min each. Finally, the bands were detected using ECL. The values were quantified and normalized to the internal control $\beta$-actin. Then, densitometric estimation was performed using ImageJ software. Each bar graph represents the mean \pm SD for at least three independent experiments.

Tumor xenografts in nude mice and experimental processes

In order to confirm the inhibitory effects of fucoidan was consistent with in vivo experiments, the nude mouse xenograft models was used. Five-week-old female Nude-Foxn $1^{\text {nu }}$ mice (BioLASCO, Taipei, Taiwan) were housed under a $12 \mathrm{~h}$ light/12 h dark cycle in a pathogen-free environment with ad libitum access to food and water. Tumors were implanted by subcutaneous (s.c.) injection of ELT-3-LUC cells $\left[1 \times 10^{6}\right.$ cells suspended in $0.1 \mathrm{ml}$ phosphate-buffered saline (PBS)/Matrigel solution for each mice] into the right flank of the mice. After the tumors reached a size of $50-100 \mathrm{~mm}^{3}$, the mice were randomly assigned to two groups (n = 3 per group): one group received a daily oral gavage of fucoidan ( $50 \mathrm{mg} / \mathrm{kg}$; treatment group) and the other group received a vehicle ( $\mathrm{ddH}_{2} \mathrm{O}$; control group) every day for 42 days. The tumor volume was measured using calipers and calculated as $\mathrm{L} \times \mathrm{W}^{2} \times 0.52$, where $\mathrm{L}$ is the length and $\mathrm{W}$ is the width. Tumor volumes and body weights were recorded until the animals were sacrificed by an i.p. injection of anesthetic mixture [1 ml Zoletil + $0.1 \mathrm{ml}$ rompun $+3.9 \mathrm{ml}$ normal saline (NS)]. Every week, the mice were administered an i.p. injection of luciferin (150 mg/kg body weight) and visualized using a Non-Invasive In vivo Imaging System (IVIS). At the end of the experiment, the tumors were formalin-fixed and stained with hematoxylin and eosin (H\&E), PCNA, fibronectin, and $\alpha$-SMA. All of the animal studies were conducted according to the protocols approved by the Institutional Animal Care and Use Committee (IACUC) of Taipei Medical University (IACUC Approval No. 2015-0447).

\section{Immunohistochemistry analysis}

To observe the localization of specific proteins were consistent with in vivo experiments, immunohistochemistry analysis was assayed. Tumor tissues were embedded and sliced at 2- or 6- $\mu$ m thick by the animal experiment center of Taipei Medical University (Taipei, Taiwan). Tissue sections were stained by BIO-CHECK LABORATORIES LTD (Taipei, Taiwan). To analyze immunohistochemistry slides, five areas were photographed at $40 \mathrm{X}$ magnifications (center, bottom, top, left and right regions) using an EVOS $^{\circledR}$ microscope (Thermo Fisher Scientific, UT, USA) and the color of the PCNA, fibronrctin and $\alpha$-SMA staining in the tissue sections was observed.

\section{Statistical analysis}

The data were presented as the mean \pm standard deviation (SD), and the differences between the means were analyzed using the Sigma Plot version 12.5. For the comparison of two groups, Student's t-test was used. Means of more than two groups of data were compared using a one-way analysis of variance (ANOVA), followed by Tukey's honestly significant difference (HSD) and Duncan's multiple-range post hoc test. The difference between two means was considered statistically significant when $p<0.05$ and highly significant when $p<0.001$.

\section{Results}

Cytotoxicity of fucoidan on leiomyoma cells and putative tumor-initiating cells

To evaluate the cytotoxic effect of fucoidan, ELT-3 were treated with fucoidan $(0,0.1$, $0.25,0.5,1 \mathrm{mg} / \mathrm{ml}$ ) for 24 and $48 \mathrm{~h}$, and cell viability was measured using the MTT assay. 


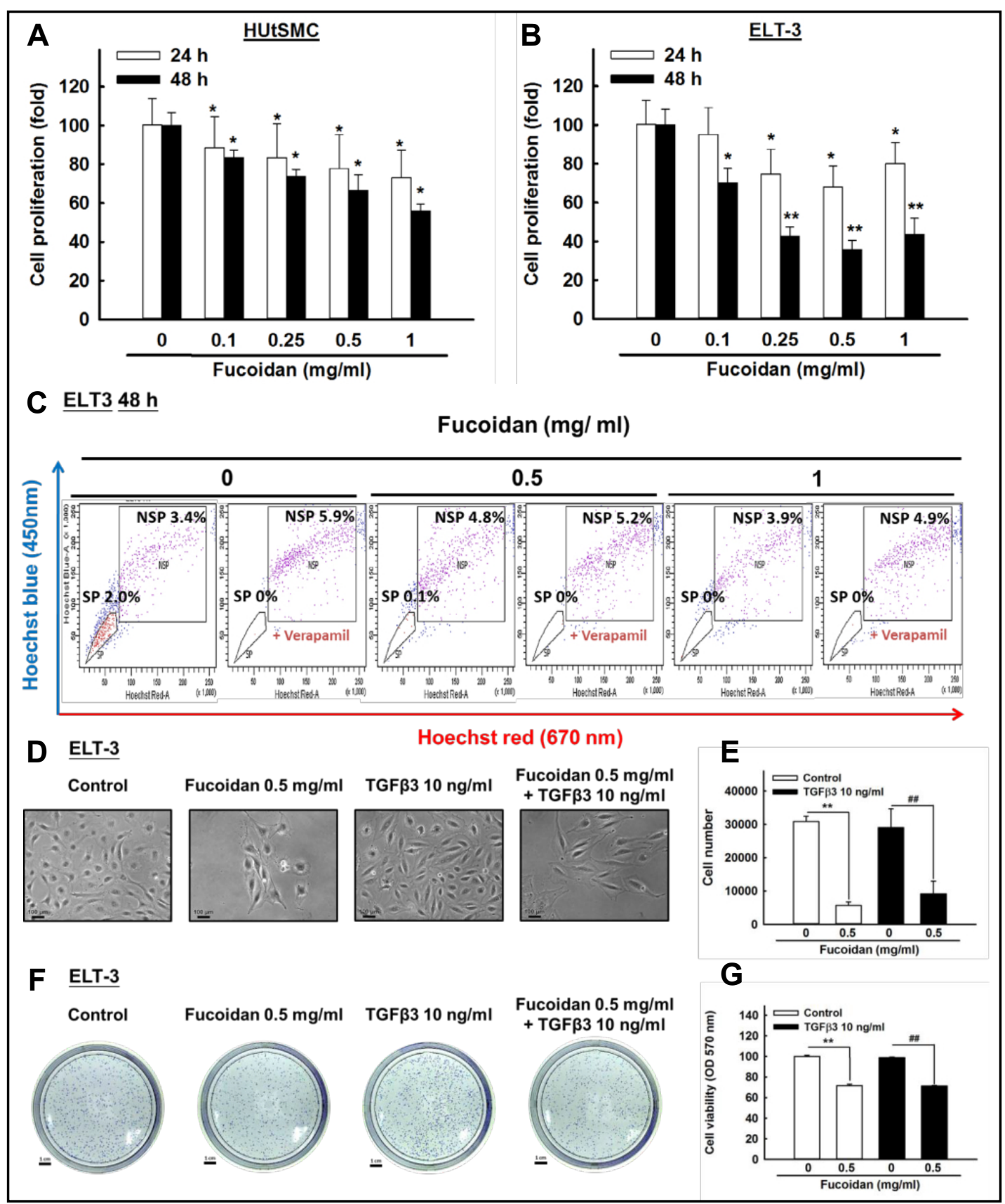

Fig. 1. Cytotoxicity of fucoidan on leiomyoma cell and putative tumor-initiating cells. (A) HUtSMC and (B) ELT-3 cells were exposed to the indicated concentration of fucoidan from 0.1 to $1 \mathrm{mg} / \mathrm{ml}$ follow by 24-48 h incubation. Cell proliferation was measured by MTT assay. (C) Analysis of side population (SP) distribution after fucoidan treatment $(0,0.5$ and $1 \mathrm{mg} / \mathrm{ml})$. Distribution of the SP and Non-SP (NSP) living cells isolated from ELT-3 leiomyoma cell fraction. SP cells represent 2\% of total living cells stained with Hoechst 33342 (fucoidan $0 \mathrm{mg} / \mathrm{ml}$ group, left panel). Co-addition of $50 \mu \mathrm{M}$ verapamil (inhibitor of $\mathrm{ABC}$ transporters) resulted in the disappearance of the SP fraction, negative control (each group, right panel) ( $\mathrm{n}=3$ ). (D) and (E) ELT-3 cells were treated with $0.5 \mathrm{mg} / \mathrm{ml}$ fucoidan and TGFß3 $10 \mathrm{ng} / \mathrm{ml}$ follow by $96 \mathrm{~h}$ incubation, then cell number were counted by eye after trypan blue stain; scale bar $=100 \mu \mathrm{m}$. (F) and (G) Cell colony formation were stain by violet crystal, and measured at $570 \mathrm{~nm}$; scale bar $=1 \mathrm{~cm}$. The results are expressed as means \pm SD of three independent experiments. Significances were calculated with one-way ANOVA analysis and Duncan's multiple-range post-test. ${ }^{*} p<0.05$ and ${ }^{* *} p<0.001$ compared with control; ${ }^{\# \#} p$ $<0.001$ compared with TGF $\beta 310 \mathrm{ng} / \mathrm{ml}$. 


\section{Cellular Physiology Cell Physiol Biochem 2018;49:1970-1986

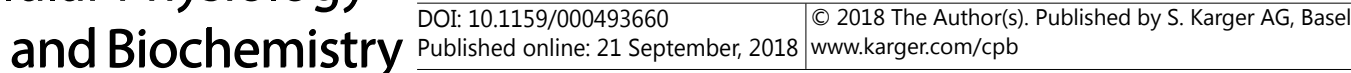 \\ Chen et al.: Anti-Proliferation Effect of Fucoidan in Leiomyoma}

Fucoidan decreased the growth of uterine leiomyoma cells in a time-dependent manner (Fig. $1 \mathrm{~A}$ and $\mathrm{B})$, and we also calculated that the half maximal inhibitory concentration $\left(\mathrm{IC}_{50}\right)$ is 2 or $0.3 \mathrm{mg} / \mathrm{ml}$ for fucoidan in HUtSMC or ELT- 3 cells, respectively. Based on the above results, we selected $0.5 \mathrm{mg} / \mathrm{ml}$ fucoidan as the concentration for the subsequent experiments.

To investigate whether leiomyomas have a population of stem cells that enable the repeatable enlargement of the uterus, we isolated putative leiomyoma stem cells from the ELT-3 leiomyoma cell fraction. Based on the side-population (SP) phenotype characteristic of the unique ability to efflux the hydrophobic fluorescent dye Hoechst 33342 via the ABCtransporter [36], we selected the putative leiomyoma stem cells and found that these cells represented $2.0 \%$ of the total living cell population (fucoidan $0 \mathrm{mg} / \mathrm{ml}$ group, left panel). However, we found that fucoidan decreased the number of selected stem cells for SP distribution (fucoidan $1 \mathrm{mg} / \mathrm{ml}$ group, left panel). In addition, separation of the SP cells was blocked by the addition of $50 \mathrm{M}$ verapamil (negative control), an $\mathrm{ABC}$ transport protein inhibitor, and resulted in the disappearance of the SP fraction (each group, right panel) (Fig. 1C).

Inhibition of TGFß3-induced cell growth in leiomyoma cells by fucoidan

According to a previous study, TGF $\beta$ is considered one of the key factors in the pathogenesis mechanism of uterine leiomyoma. To simulate the generated state of uterine leiomyoma, we also used TGF $\beta$ to stimulate ELT- 3 cell growth; simultaneously, the cells were co-treated with fucoidan to inhibit the cell viability induced by TGF $\beta 3$ treatment. In Fig. 1D, after induction by TGF $\beta 3$ treatment, ELT-3 cells were spindle-shaped and had elongated nuclei for $96 \mathrm{~h}$, but rounded floating cells were observed after $0.5 \mathrm{mg} / \mathrm{ml}$ fucoidan alone or co-treatment with $10 \mathrm{ng} / \mathrm{ml}$ TGF $\beta 3$. In addition, using the trypan blue exclusion test to examine the cell viability of ELT-3, as shown in Fig. $1 \mathrm{E}, 0.5 \mathrm{mg} / \mathrm{ml}$ fucoidan alone or cotreatment with $10 \mathrm{ng} / \mathrm{ml}$ TGF $\beta 3$ significantly reduced the number of ELT-3 cells for $96 \mathrm{~h}$. Colony formation assays are often used to examine the long-term inhibitory effects on cell viability. We found that the colony formation number of ELT-3 was significantly decreased after fucoidan treatment compared with controls for 5 days. Similarly, when co-treated with TGF 33 , fucoidan treatment also significantly suppressed the colony formation number of ELT-3 compared with the TGF 33 alone group (Fig. 1F and G).

\section{Effects of fucoidan on cell cycle progression at sub-G1 phase and apoptosis-associated protein expression}

To further investigate whether the cytotoxicity of fucoidan is associated with cell cycle arrest, we examined its effects on cell cycle progression and the results showed that $0.5 \mathrm{mg} /$ $\mathrm{ml}$ fucoidan arrested the cell cycle at the sub-G1 checkpoint phase (Fig. 2A and C) and caused the protein expression of cyclin D1 was decreased in ELT-3 cells (Fig. 2D and F). In addition, when co-treated with TGF $\beta 3$, fucoidan treatment also increased the percentage of sub G1 phase (Fig. 2A and C) and caused cyclin D1 protein expression significantly decrease in ELT-3 cells (Fig. 2D and F) compared with the TGF 33 alone group. Then, we investigated whether fucoidan induced apoptosis in leiomyoma cells using FACS analysis with Annexin V-FITC and PI double staining and the results showed that the percentage of apoptotic cells significantly increased from $3.9 \%$ to $24 \%$ in ELT-3 cells after treatment with $0.5 \mathrm{mg} / \mathrm{ml}$ fucoidan for $72 \mathrm{~h}$ (Fig. 2G and I). Similarly, when co-treated with TGF 3 , fucoidan treatment also significantly increased the percentage of apoptotic cells compared with the TGF $\beta 3$ alone group (Fig. 2G and I). In addition, the apoptosis-associated protein (Bax/Bcl-2 ratio) levels were increased in ELT-3 cells after $0.5 \mathrm{mg} / \mathrm{ml}$ fucoidan treatment (Fig. $2 \mathrm{H}$ and J). Our results demonstrated that fucoidan-induced apoptosis was mainly associated with an increase in the number of apoptotic cells (sub-G1 population).

Fucoidan ameliorates TGF 33 -induced extracellular matrix (ECM) accumulation in vitro

Numerous studies have shown that TGF $\beta$ can enhance excessive ECM production and storage in uterine leiomyoma. As western blot analysis showed, TGF $\beta 3$ treatment enhanced 
Fig. $\quad 2$.

$\mathrm{F}$ u c o id a $\mathrm{n}$

i $\mathrm{n} \mathrm{d} \mathrm{u} \mathrm{c} \mathrm{e} \mathrm{s}$ sub-G1 cell cycle arrest and apoptosis in leiomyoma cell lines. Cells were plated in 100 $\mathrm{mm}$ diameter dishes at $2 \mathrm{x}$ $10^{5}$ cells in medium with $10 \%$ FBS until attach the plate bottom. ELT-3 cells were cotreated with $0.5 \quad \mathrm{mg} / \mathrm{ml}$ fucoidan and TGFß3 $10 \mathrm{ng} /$ ml for $72 \mathrm{~h}$. (A) The cells were stained with propidiu m iodide (PI), and the his tograms of cell cycle distribution was analyzed by flow cytometry. The vertical axis represents the cell numbers; the horizontal axis represents the PI stained strength. (B) and (C) The cell cycle distribution was shown in bar graph. The vertical $\mathrm{n} \mathrm{u} \mathrm{m} \mathrm{b} \mathrm{e} \mathrm{r} \mathrm{s}$ represents the

A ELT-3

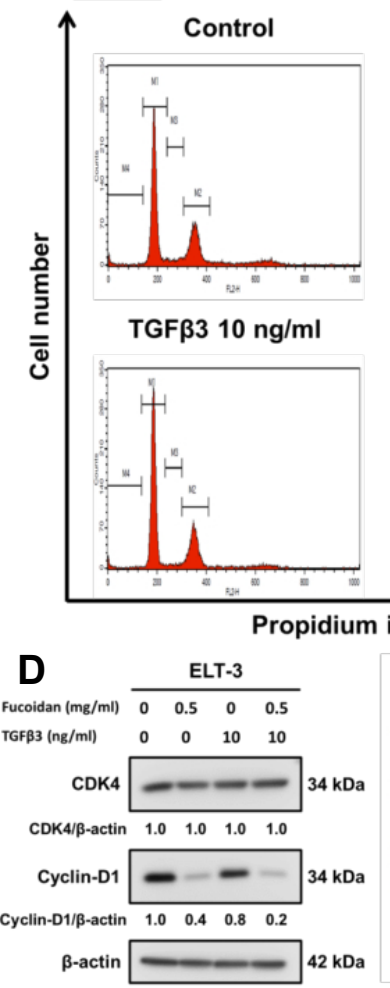

\section{G ELT-3}

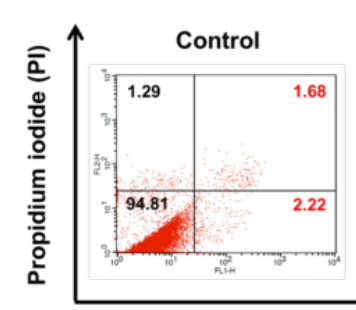

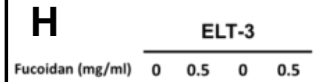
$\begin{array}{ccccc}T G F B 3 & (\mathrm{ng} / \mathrm{ml}) \quad 0 & 0 & 10 & 10\end{array}$

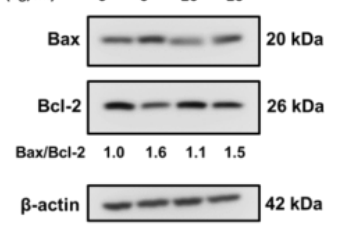

\section{B}


Fucoidan $0.5 \mathrm{mg} / \mathrm{ml}$ + TGF $\beta 310 \mathrm{ng} / \mathrm{ml}$
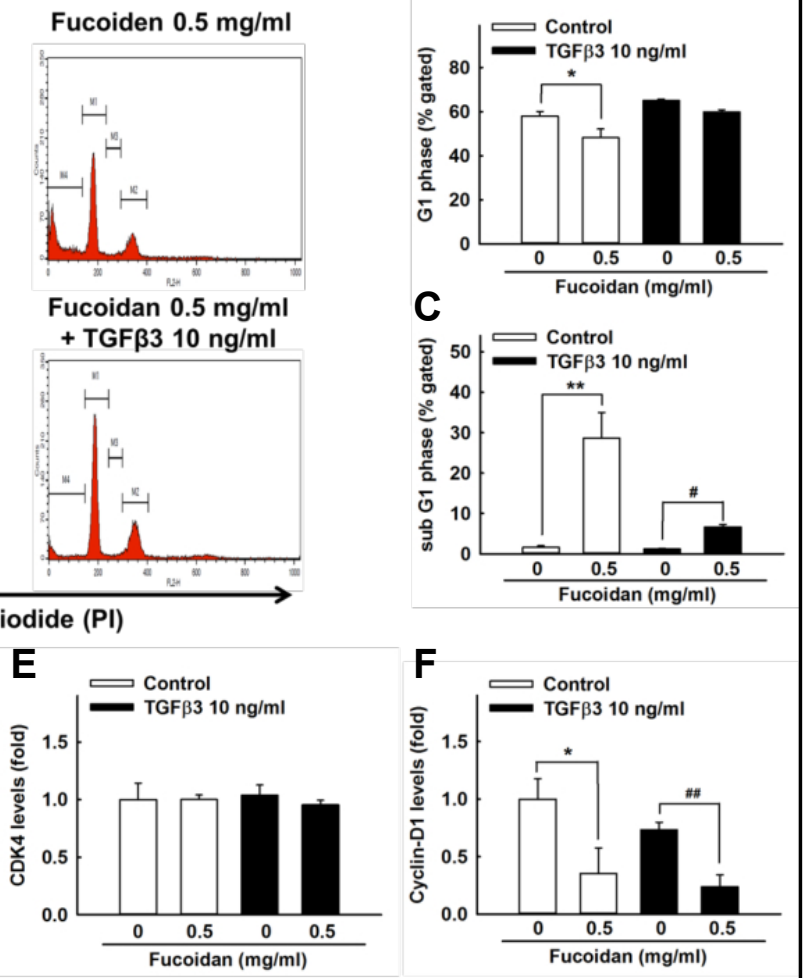

cell population percentage in cell cycle G1 and sub-G1 phase, the horizontal number represents the dose of fucoidan. (G) ELT-3 cells were harvested and stained with Annexin V-fluorescein isothiocyanate (FITC) and $\mathrm{PI}$, and cell apoptosis was analyzed using flow cytometry. (I) The percentage of apoptosis was shown in bar graph. (D) and (H) ELT-3 cell lysates were separated by SDS-PAGE and analyzed by western blot with the indicated antibodies. $\beta$-actin was used as a loading control. The values of the band intensity represent the densitometric estimation of each band normalized to $\beta$-actin. Protein quantification of CDK4 (E), cyclin-D1 (F), and Bax to Bcl-2 (J) expression in ELT-3 cells was shown in bar graph. Significances were calculated with one-way ANOVA analysis and Tukey's HSD post-test. ${ }^{*} p<0.05$ and ${ }^{* *} p<0.001$ compared with control; ${ }^{*} p<$ 0.05 and ${ }^{\# \#} p<0.001$ compared with TGFB3 $10 \mathrm{ng} / \mathrm{ml}$.

\section{KARGER}




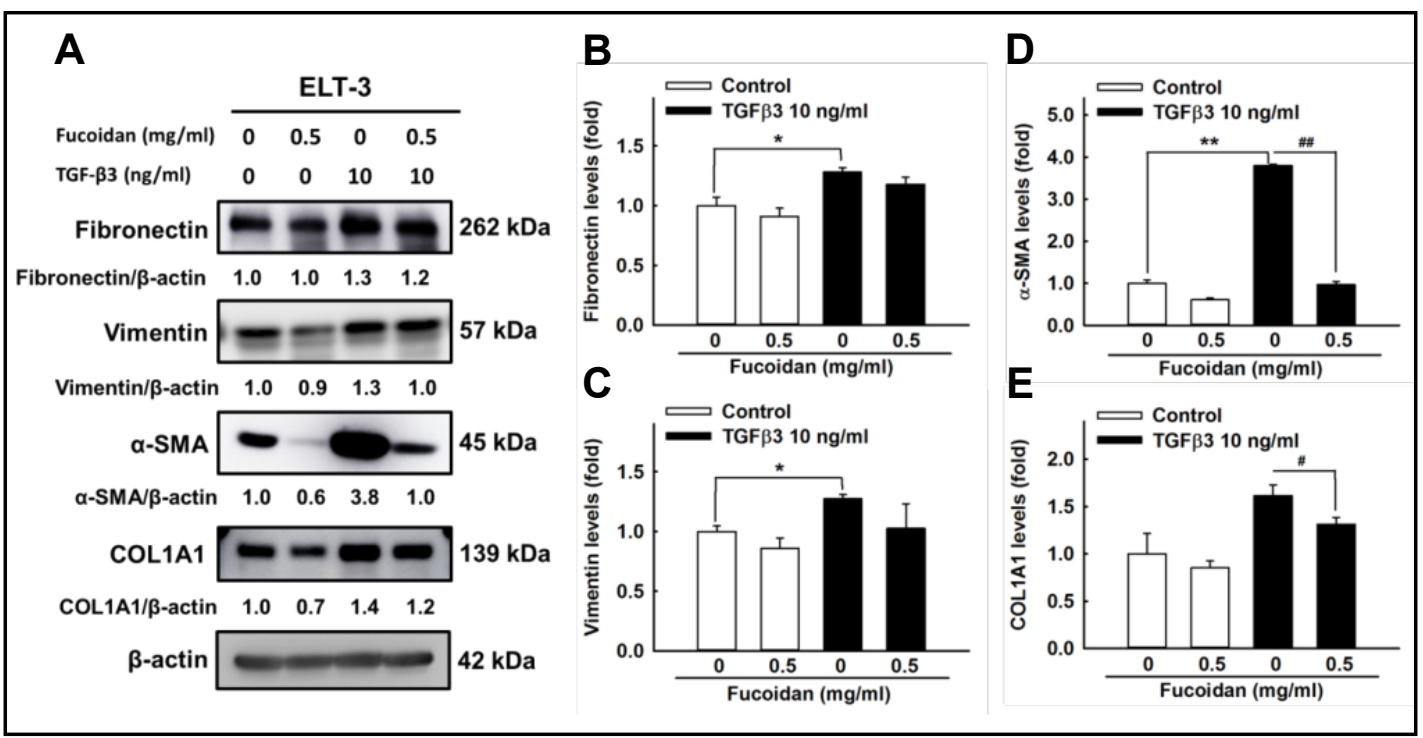

Fig. 3. Effect of fucoidan and TGF $\beta 3$ on protein expressions of ECM-related protein in ELT- 3 cells. ELT- 3 cells were co-treated with $0.5 \mathrm{mg} / \mathrm{ml}$ fucoidan and TGF $3310 \mathrm{ng} / \mathrm{ml}$ for $48 \mathrm{~h}$. (A) ELT-3 cell lysates were separated by SDS-PAGE and analyzed by western blot with anti-fibronectin, vimentin, $\alpha$-SMA, and COL1A1. $\beta$-actin was used as a loading control. The values of the band intensity represent the densitometric estimation of each band normalized to $\beta$-actin. Protein quantification of fibronectin (B), vimentin (C), $\alpha$-SMA (D), and COL1A1 (E) expression in ELT-3 cells was shown in bar graph. Significances were calculated with one-way ANOVA analysis and Tukey's HSD post-test. ${ }^{*} p<0.05$ and $^{* *} p<0.001$ compared with control; ${ }^{\#} p<0.05$ and ${ }^{\# \#} p<0.001$ compared with TGFß3 $10 \mathrm{ng} / \mathrm{ml}$.

excessive deposition of ECM proteins, such as significantly enhanced the level of fibronectin, vimentin, and $\alpha$-SMA, as well as up-regulating the expression of COL1A1 compared to controls. To investigate whether fucoidan decreased ECM accumulation in leiomyoma cells, we cotreated with fucoidan and TGF $\beta 3$ and found that fucoidan abrogated the protein expression of fibronectin, vimentin, $\alpha$-SMA, and COL1A1 after induction by TGF 33 treatment (Fig. 3A-E). These data demonstrated the potent inhibitory effect of fucoidan on ECM accumulation in leiomyoma in vitro.

Profibrotic response of TGF 33 in ELT-3 cells is mediated by $\beta$-catenin, Smad and non-Smad ERK1/2 signaling pathways

To clarify whether fucoidan and TGF $\beta 3$ could affect the level of $\beta$-catenin in ELT- 3 cells, western blot analysis was performed. We found that fucoidan reduced the level of $\beta$-catenin in the cytoplasm and therefore abrogated the TGF $\beta 3$-induced level of $\beta$-catenin translocation into the nucleus in ELT-3 cells (Fig. 4A-D). In addition, we also investigated whether fucoidan could regulate the mechanism under the TGF $\beta 3$-induced Smad pathway. As indicated in Fig. $4 \mathrm{E}$ and $\mathrm{G}$, we found that TGF 33 induced the expression of phosphorylated Smad2 after 4 $\mathrm{h}$, whereas $0.5 \mathrm{mg} / \mathrm{ml}$ fucoidan abrogated TGF $\beta 3$-induced the phosphorylation of Smad2 protein. Then, we determined whether fucoidan also modulated the TGF $\beta 3$-induced non-Smad pathway. As shown in Fig. 4E and $\mathrm{H}$, we found that fucoidan decreased the phosphorylation of ERK1/2 protein, which was induced by TGF $\beta 3$ treatment. Taken together, these data showed that fucoidan inhibition of cell viability in leiomyoma cells partly involves targeting T $\beta R 2$, with the consequent attenuation of the $\beta$-catenin, Smad2 and ERK1/2 signaling pathways.

Inhibition of ULs growth and ECM accumulation in vivo by fucoidan

To investigate whether fucoidan can inhibit the growth of leiomyoma in vivo, we used ELT3 -LUC-xenografted mice as an experimental model. The treatment group received fucoidan (50 mg/kg) or vehicle $\left(\mathrm{ddH}_{2} \mathrm{O}\right.$, control) via oral gavage every day for 42 days. During the 


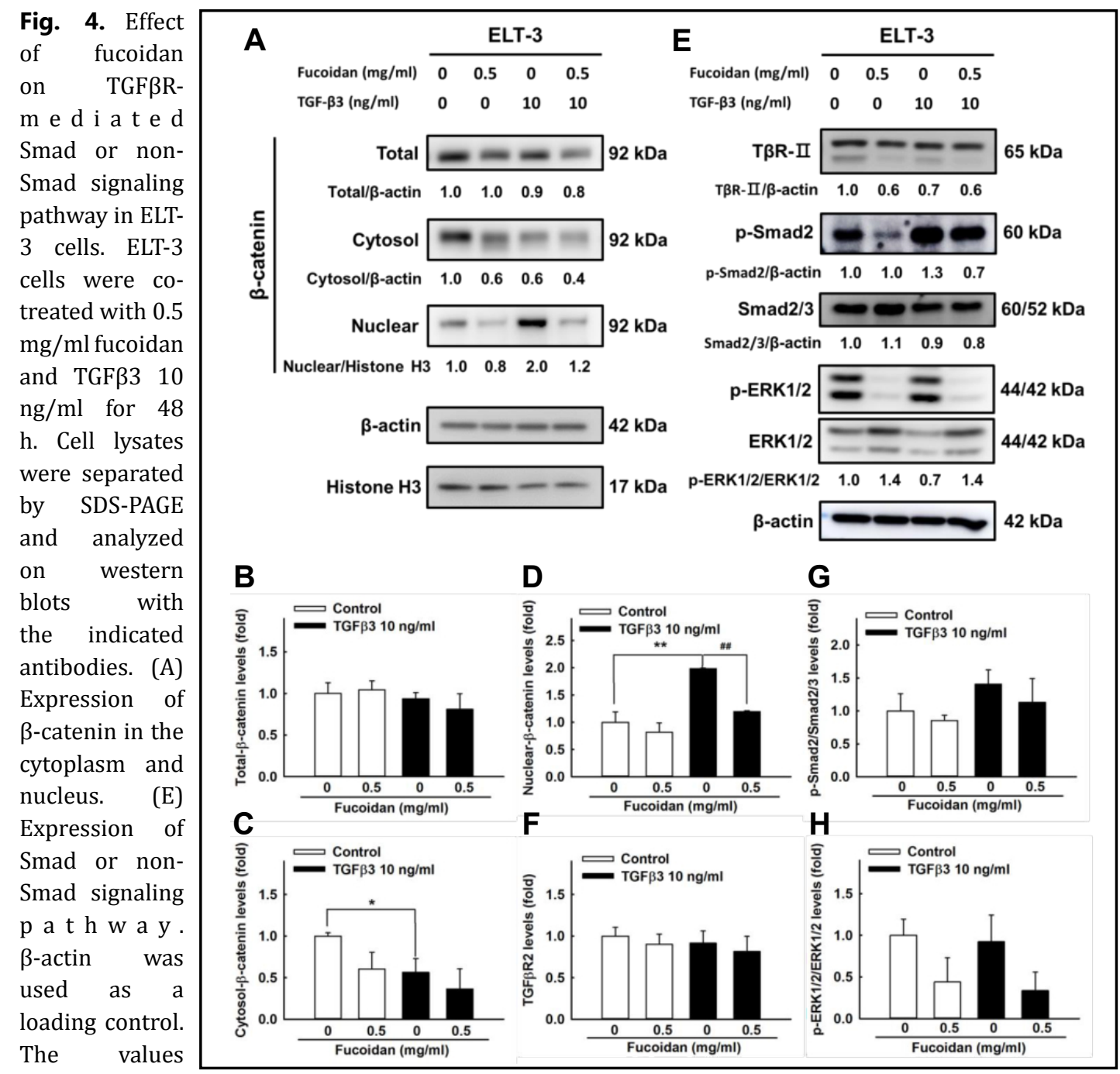

of the band

intensity represent the densitometric estimation of each band normalized by $\beta$-actin or Histone H3. Protein quantification of total- $\beta$-catenin (B), cytosol- $\beta$-catenin (C), nuclear- $\beta$-catenin (D), T $\beta \mathrm{R}-\mathrm{II}$ (F), p-Smad2 to Smad2/3 (G), and p-ERK1/2 to ERK1/2 (H) expression in ELT-3 cells was shown in bar graph. Significances were calculated with one-way ANOVA analysis and Tukey's HSD post-test. ${ }^{*} p<0.05$ and $^{* *} p<0.001$ compared with control; $\# \#<0.001$ compared with TGFß3 $10 \mathrm{ng} / \mathrm{ml}$.

treatment period, the body weights of the mice were measured each time they were gavaged to determine the possible side effects of fucoidan treatment on the overall health of the mice. IVIS in conjunction with a firefly bioluminescent enzyme was used to progressively track the growth of ELT-3-LUC tumors after fucoidan treatment in the mouse xenograft model (Fig. 5A). No significant difference in body weights of the mice was observed between the groups (Fig. 5B). Notably, a significant difference in tumor weight and volumes was observed between the control- and fucoidan-treated groups on day 42 of treatment (Fig. 5C and D). In addition, IVIS images showed an increase in bioluminescent signal strength in the control group, and in the quantitative chart (Fig. 5E), fucoidan-treated groups have significantly lower photon counts $(p<0.05)$ compared with the control group. These data demonstrated the potent inhibitory effect of fucoidan on the growth of ULs within a relatively short treatment period.

To confirm the results of the animal study further, immunohistochemistry analysis was performed. Compared with the control group, the fucoidan-treated group showed a decrease in the proportion of PCNA (growth-promoting marker, Fig. 5H and I)-, fibronectin (ECM 


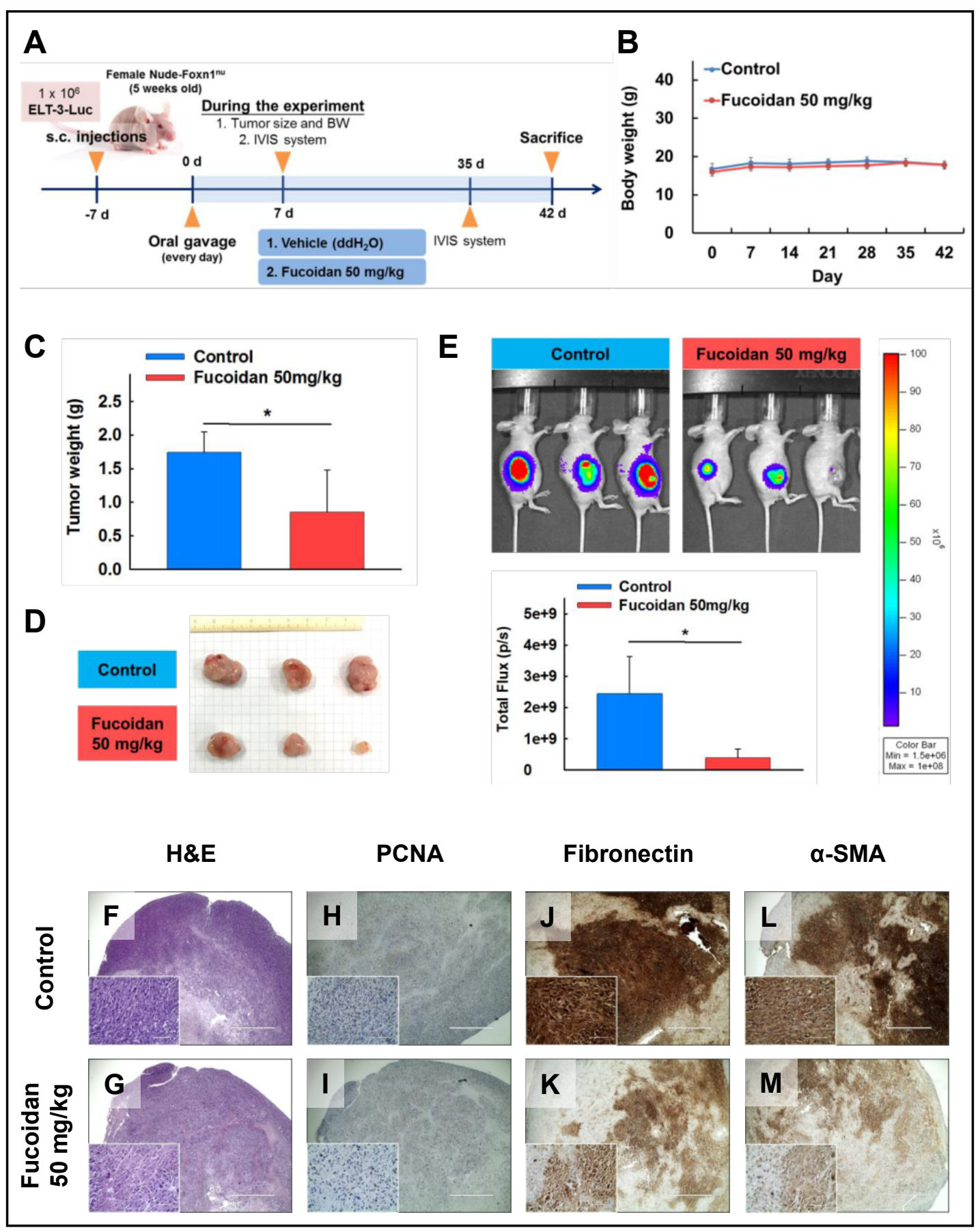

Fig. 5. In vivo effects of fucoidan using an ELT-3-LUC mouse xenograft model. (A) Schematic representation of treatment plan for ELT-3-LUC-xenografted mice. Tumors were implanted into the mice ( $\mathrm{n}=3$ per group) by subcutaneous injection of ELT-3-LUC cells $\left(1 \times 10^{6}\right.$ cells/100 $\mu \mathrm{l}$ PBS/Matrigel=1:1) on the right flank. After the tumors reached $50-100 \mathrm{~mm}^{3}$ in size, the mice received every day with oral gavage of fucoidan (50 $\mathrm{mg}$ / $\mathrm{kg}$ ) or vehicle $\left(\mathrm{ddH}_{2} \mathrm{O}\right)$ for 42 days. (B) Body weight changes of the nude mice were measured. (C) and (D) Tumor weight and morphology of each group at day 42 after the treatment. (E) Total flux from luciferase imaging after heterotopic tumor cell injection. Significances were calculated with Student's t-test. ${ }^{*} p<0.05$ compared with control. (F-M) Analysis of ELT-3-LUC tumor after fucoidan treatment. Tumors were excised and processed for hematoxylin and eosin (H\&E) staining and immunohistochemical analysis of proliferating cell nuclear antigen (PCNA), fibronectin and alpha smooth muscle Actin ( $\alpha$-SMA). Original magnification, $\times 200$. 


\section{Cellular Physiology Cell Physiol Biochem 2018;49:1970-1986

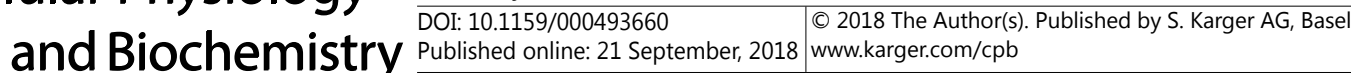 \\ Chen et al.: Anti-Proliferation Effect of Fucoidan in Leiomyoma}

marker, Fig. 5J and K)-, and $\alpha$-SMA (myofibroblast marker, Fig. 5L and M)-positive cells, as well as hematoxylin and eosin staining (H\&E stain, Fig. 5F and G). These data demonstrated that fucoidan suppress tumor progression and ECM accumulation in leiomyoma in vivo.

\section{Discussion}

In this study, we aimed to investigate the inhibitory effect of fucoidan on ULs growth both in ELT-3 cells and in a mouse xenograft model, and we found that fucoidan has potential benefits in inhibiting the growth of leiomyoma cells via decreasing ECM accumulation in vitro and in vivo.

In the inflammatory state, some factors, such as TGF $\beta$ s, activin-A, TNF- $\alpha$ and estrogen, contribute to the differentiation into myofibroblasts during fibrosis. In general, myofibroblasts generate ECM to support tissue repair and homeostasis. However, during chronic inflammation, myofibroblasts are not limited by apoptosis and generate excessive contractions and ECM protein secretion (like collagen, fibronectin, etc.), leading to pathological fibrosis [8]. Current evidence suggests that $\alpha$-SMA is a key component supporting tissue contraction of ECM [37]. Previous studies have demonstrated that $\alpha$-SMA is elevated in leiomyoma compared to myometrium [38]. Yan et al. also found that the expression of $\alpha$-SMA was significantly increased at $5 \mathrm{ng} / \mathrm{ml}$ TGF $\beta 1$ compared with the control in cardiac myocyte H9c2 cells [39]. In addition, fibronectin mRNA expression was higher in leiomyoma than in autologous myometrium, and the increase caused by TGF $\beta 3$ was markedly higher than the one caused by TGF $\beta 1$ [9]. Similarly, Levy et al. demonstrated that untreated leiomyoma showed a 2 -fold increase in fibronectin protein concentration compared with untreated myometrial cells. Additionally, TGF 33 treatment enhanced the expression of fibronectin in both myometrial and leiomyoma cells [40]. Earlier studies demonstrated that collagen type 1 (COL1A1) protein production was higher in untreated leiomyoma than myometrial cells, while Joseph et al. demonstrated that elevating TGF 33 concentration of $0.1 \mathrm{ng} / \mathrm{mL}$ to $10 \mathrm{ng} / \mathrm{mL}$ resulted in concentration-dependent increase in COL1A1 in both myometrial and leiomyoma cells [41]. Our results from the histopathological analysis of the fucoidantreated $(50 \mathrm{mg} / \mathrm{kg}$ ) group showed a lower expression of fibronectin and $\alpha$-SMA on ELT-3LUC-xenografted mice compared to the control group in vivo. In addition, in vitro experiment results also confirmed that fucoidan abrogates the TGF $\beta 3$-induced protein expression of fibronectin, $\alpha$-SMA and COL1A1 in ELT-3 cells compared to controls.

The TGF $\beta$ superfamily comprises multifunctional peptides that have diverse biological activities, including regulating cell growth and differentiation and promoting ECM production [42]. The TGF $\beta$ subtypes consist of three isoforms (TGF $\beta 1$, TGF $\beta 2$ and TGF $\beta 3$ ) that have been found in mammals. The different TGF $\beta$ isoforms have their own receptors to regulate signaling pathways [43]. According to previous studies, the TGF $\beta 3$ isoform is the major inductor of elevated ECM production and decreased ECM degradation factor production in uterine leiomyoma [41]. Furthermore, uterine leiomyoma has 5 -fold higher levels of TGF 33 mRNA expression than autologous myometrium [11]. Therefore, we hypothesized that TGFß3 would contribute to the dysregulated ECM in leiomyomas.

According to a previous study, the detection of the SP cell phenotype by Hoechst 33342 exclusion can identify cancer stem-like cells [36]. Human leiomyoma SP cells exhibit the potential ability of tumor-initiating cells, including a hypoxic cell culture proliferation ability, in vitro differentiation into adipocytes and osteocytes, and the capacity to give rise to leiomyoma-like tissue in vivo [44]. In our study, we also isolated putative leiomyoma stem cells from the ELT-3 leiomyoma cell fraction and found that these cells represented $2.0 \%$ of the total living cell population (fucoidan $0 \mathrm{mg} / \mathrm{ml}$ group, left panel). However, fucoidan treatment decreased the number of selected stem cells for SP distribution at $1 \mathrm{mg} / \mathrm{ml}$, indicating that fucoidan can inhibit the activity of leiomyoma stem-like cells.

Cell growth and differentiation depend on the cell cycle. The cell cycle consists of four distinct phases: G1, S, G2 and M phase. In addition, cells can enter a state of quiescence called 


\section{Cellular Physiology Cell Physiol Biochem 2018;49:1970-1986

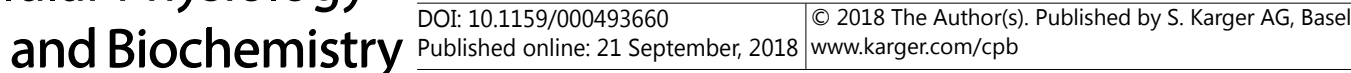 \\ Chen et al.: Anti-Proliferation Effect of Fucoidan in Leiomyoma}

G0 phase [45]. G1 progression and entry into S phase are controlled by cyclins D, which have been reported to be overexpressed in uterine leiomyoma compared with autologous myometrium [46]. According to the study from Cho et al, the treatment of bladder cancer cells with fucoidan induced G0/G1 phase arrest via a decreased expression level of cyclin D1/CDK4 and cyclin E/CDK2 [29]. Our results also demonstrated that fucoidan can induce sub-G1 phase arrest and down-regulated the protein expression of cyclin D1 in ELT-3 cells.

In general, sub G0/G1 cell accumulation suggests that dead cells/apoptotic cells are present. Several studies have also shown that fucoidan mediated cell death via triggering apoptosis. Treatment with $820 \mu \mathrm{g} / \mathrm{mL}$ of low molecular weight (LMW) fucoidan resulted in a significant decrease in anti-apoptotic proteins Bcl-2, Bcl-xl and Mcl-1 in MDA-MB231 breast cancer cells [35]. Similarly, Xue et al. also demonstrated that fucoidan treatment downregulated the expression of Bid, Bcl-2 and Bcl-xl and up-regulated the level of Bax, especially at $25 \mu \mathrm{g} / \mathrm{ml}$ in MDA-MB231 breast cancer cells [47]. Our study had similar results, where fucoidan induced apoptosis via up-regulation of the Bax/Bcl-2 ratio in ELT-3 cells. As Bcl-2 family members are mainly involved in the intrinsic apoptosis pathway, we assume fucoidan can induce the intrinsic apoptosis pathway in our study.

The in vivo experiments verified our in vitro findings on the anti-proliferation and antifibrotic effects of fucoidan against leiomyoma. During the experiment for 42 days, we found that the fucoidan-treated $(50 \mathrm{mg} / \mathrm{kg}$ ) group had significantly reduced tumor volume in ELT-3LUC xenograft mice compared with the control group. Similarly, Hsu et al. demonstrated that fucoidan-induced a marked dose-dependent reduction of tumor volume in male C57BL/6 mice xenografted with Lewis lung carcinoma (LLC1) cells, especially at a concentration of $96 \mathrm{mg} / \mathrm{kg}$ for 21 days, indicating that fucoidan exerted anti-tumor activity in vivo [48]. PCNA, which is a coenzyme of DNA polymerase that is involved in the synthesis of DNA in the nucleus, is commonly used as a marker of cell proliferation [49]. Our histopathological analysis showed that the proportion of PCNA-positive cells was decreased in the fucoidantreated group at 42 days. Similar effects were reported in studies by Zhang et al, which demonstrated that EGCG treatment decreased the number of PCNA-positive cells at 4 and 8 weeks compared with water treatment (control) [14].

Many studies have demonstrated that TGF $\beta$ superfamily signaling is essential for female reproduction and that abnormal TGF $\beta$ signaling may promote reproductive diseases or cancers. TGF $\beta$ signals through a Smad-dependent (i.e., canonical) pathway to regulate the transcription of several target genes. In addition, intracellular signaling activated by TGF $\beta$ also includes Smad-independent (i.e., non-canonical) pathways, including various branches of MAP kinase pathways, Rho-like GTPase signaling pathways, and phosphatidylinositol-3kinase/AKT pathways $[42,50]$.

ERK1/2 signaling can regulate proliferation, survival, and apoptosis in a variety of cell types. $17 \beta$-estradiol (E2) exposure rapidly activates ERK1/2 in leiomyoma cells but not in normal myometrium, indicating that aberrant ERK1/2 signaling occurs in leiomyoma [51]. In our study, we demonstrated that TGF $\beta 3$ binds to T $\beta$ R2, leading to phosphorylated Smad 2 and ERK1/2 level increases and ultimately gene transcription activation. However, fucoidan abrogates TGF 33 -induced protein expression of phosphorylated Smad2 and ERK1/2. Hsu et al. found similar effects in lung cancer cells, as TGF $\beta 1$ stimulation enhanced the phosphorylation of Smad2/3, Akt, and ERK1/2 but fucoidan abolished the TGF $\beta 1$-induced phosphorylation of these molecules [48]. In addition, several studies also investigated these signaling pathway with different treatment, such as Loureirin B (LB), He et al. found that LB inhibited the up-regulation of $\mathrm{p}$-ERK that was induced by TGF $\beta 1$ in hypertrophic scar tissue [52].

Activated $\beta$-catenin is associated with proliferation and ECM formation in human leiomyoma tissue [53]. Ono et al. have demonstrated that the downregulation of WNT/ $\beta$ catenin signaling, via inhibitor of $\beta$-catenin and TCF4 (ICAT), niclosamide, or XAV939, has antitumor effects on primary cultures of human leiomyoma cells in vitro [54]. TGF $\beta$ facilitates the translocation of un-phosphorylated $\beta$-catenin from the cytoplasm to the nucleus [55], 
Fig. 6. Schematic diagram of the mechanism of fucoidan inhibits the growth of uterine leiomyoma. Fucoidan significantly abolished the cell viability of ELT-3 cells induced by TGF $\beta 3$, and promote sub-G1 phase arrest and apoptosis occur. Fucoidan also abrogated the ECM proteins up-regulated by TGF $\beta 3$ in ELT-3 cell via TGF $\beta R$ mediated Smad and ERK1/2 signaling pathway.

and via integration with the T-cell factor and lymphoid enhancer factor-1 (TCF/LEF1) family of transcription factors to activate WNT target gene expression [56]. In our study, we found that fucoidan treatment decreased the levels of $\beta$-catenin in both the cytoplasm and

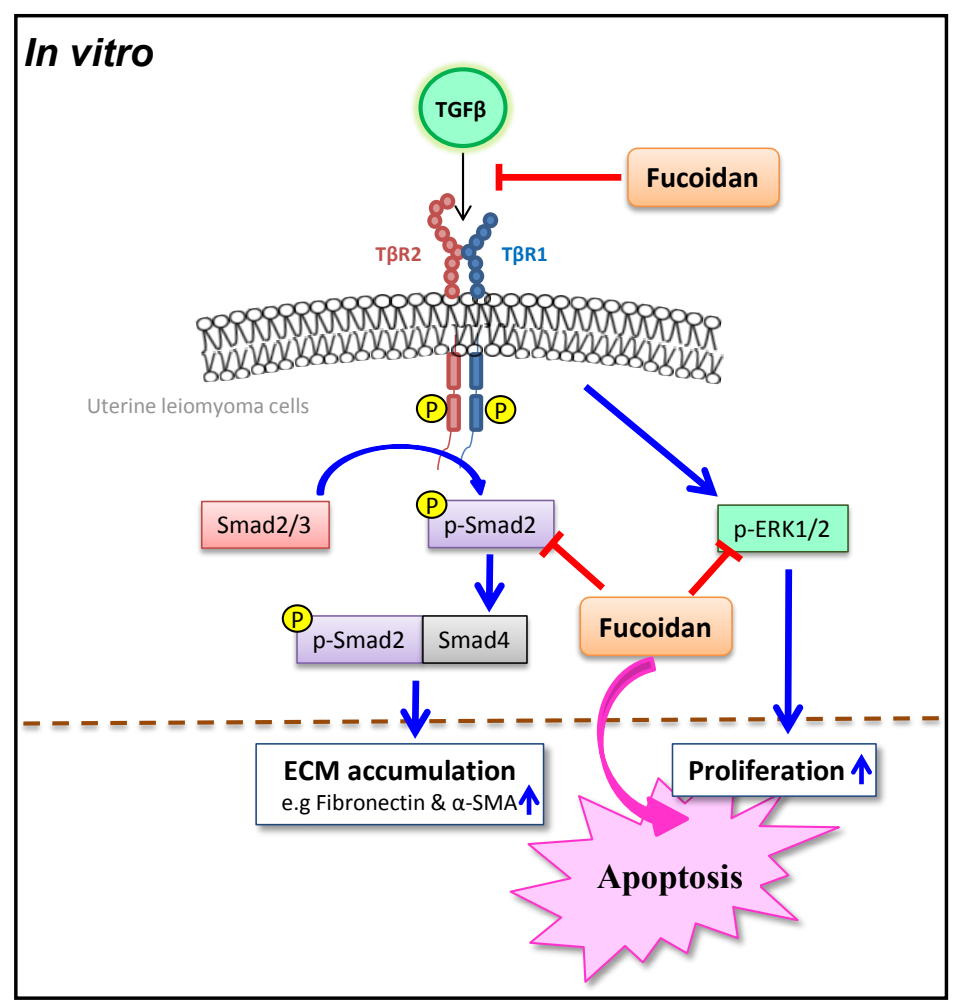
the nucleus in ELT-3 cells and abolished the TGF $\beta 3$ induced $\beta$-catenin translocation into the nucleus. Similarly, Xue et al. demonstrated that fucoidan treatment decreased the levels of $\beta$-catenin in the cytoplasm and nucleus of MDAMB-231 cells [47].

\section{Conclusion}

The present study demonstrated that fucoidan significantly decreased the cell viability and stem cell activity of ELT- 3 cells. In addition, fucoidan abolished the effect of TGF 33 and induced sub-G1 phase arrest and apoptosis. Fucoidan also abrogated ECM protein upregulation by TGF $\beta 3$ in ELT-3 cells via TGF $\beta$ R-mediated Smad and ERK1/2 signaling pathways, providing a potential novel therapy in preventing hyperplasia of leiomyoma cells in vitro (Fig. 6). Furthermore, fucoidan suppresses tumor growth and decreased the expression of PCNA, fibronectin and $\alpha$-SMA in tumor tissue in vivo. To the best of our knowledge, this is the first study to demonstrate the inhibitory potential of fucoidan on ULs growth in vivo and may encourage further studies to highlight the molecular mechanism involving fucoidan and ULs.

\section{Abbreviations}

ULs (Uterine leiomyoma); ELT-3 (Eker uterine leiomyoma cells); HUtSMC (Human uterine smooth muscle cells); ECM (Extracellular matrix); TGF $\beta$ (Transforming growth factor beta); PCNA (Proliferating cell nuclear antigen); $\alpha$-SMA (Alpha-smooth muscle actin); SDSPAGE (Sodium dodecyl sulfate polyacrylamide gel electrophoresis); IVIS (In vivo Imaging System); SP (Side population); CDKs (Cyclin-dependent kinase). 


\section{Cellular Physiology Cell Physiol Biochem 2018;49:1970-1986 and Biochemistry Published \begin{tabular}{l|l} 
DOI: 10.1159/000493660 & $\begin{array}{l}\text { (c) } 2018 \text { The Author(s). Published by S. Karger AG, Basel } \\
\text { www.karger.com/cpb }\end{array}$
\end{tabular} \\ Chen et al.: Anti-Proliferation Effect of Fucoidan in Leiomyoma}

\section{Acknowledgements}

This study was supported by the grants (MOST106-2320-B-038-064-MY3, MOST1032313-B-038-003-MY3 and NSC102-2313-B-038-001) from the Ministry of Science and Technology and (106AS-16.4.1-ST-a4) from Council of Agriculture, Taiwan, Republic of China.

SMH designed this research. HYC carried out most of the experiments, analyzed the data, drew the figures and drafted this manuscript. TCH and LCL helped with cell culture, western blot experiments and animal experiments. All authors read and approved the final manuscript.

\section{Disclosure Statement}

The authors declare that they have no competing interests.

\section{References}

1 Wallach EE, Buttram VC, Reiter RC: Uterine leiomyomata: etiology, symptomatology, and management. Fertility and Sterility 1981;36:433-445.

$>2$ Cramer SF, Patel A: The frequency of uterine leiomyomas. Am J Clin Pathol 1990;94:435-438.

- Islam MS, Protic 0, Giannubilo SR, Toti P, Tranquilli AL, Petraglia F, Castellucci M, Ciarmela P: Uterine leiomyoma: available medical treatments and new possible therapeutic options. J Clin Endocrinol Metab 2013;98:921-934.

4 Okolo S: Incidence, aetiology and epidemiology of uterine fibroids. Best Pract Res Clin Obstet Gynaecol 2008;22:571-588.

5 Segars JH, Parrott EC, Nagel JD, Guo XC, Gao X, Birnbaum LS, Pinn VW, Dixon D: Proceedings from the Third National Institutes of Health International Congress on Advances in Uterine Leiomyoma Research: comprehensive review, conference summary and future recommendations. Hum Reprod Update 2014;20:309-333.

6 Ono M, Maruyama T, Masuda H, Kajitani T, Nagashima T, Arase T, Ito M, Ohta K, Uchida H, Asada H, Yoshimura Y, Okano H, Matsuzaki Y: Side population in human uterine myometrium displays phenotypic and functional characteristics of myometrial stem cells. Proc Natl Acad Sci U S A 2007;104:18700-18705.

7 Wynn TA: Common and unique mechanisms regulate fibrosis in various fibroproliferative diseases. J Clin Invest 2007;117:524-529.

-8 Islam MS, Ciavattini A, Petraglia F, Castellucci M, Ciarmela P: Extracellular matrix in uterine leiomyoma pathogenesis: a potential target for future therapeutics. Hum Reprod Update 2018;24:59-85.

$>9$ Arici A, Sozen I: Transforming growth factor-beta3 is expressed at high levels in leiomyoma where it stimulates fibronectin expression and cell proliferation. Fertil Steril 2000;73:1006-1011.

10 Leppert PC, Baginski T, Prupas C, Catherino WH, Pletcher S, Segars JH: Comparative ultrastructure of collagen fibrils in uterine leiomyomas and normal myometrium. Fertil Steril 2004;82 Suppl 3:1182-1187.

-11 Lee BS, Nowak RA: Human leiomyoma smooth muscle cells show increased expression of transforming growth factor-beta 3 (TGF beta 3) and altered responses to the antiproliferative effects of TGF beta. J Clin Endocrinol Metab 2001;86:913-920.

$\checkmark 12$ Commandeur AE, Styer AK, Teixeira JM: Epidemiological and genetic clues for molecular mechanisms involved in uterine leiomyoma development and growth. Hum Reprod Update 2015;21:593-615.

13 Wu CH, Shieh TM, Wei LH, Cheng TF, Chen HY, Huang TC, Wang KL, Hsia SM: Resveratrol inhibits proliferation of myometrial and leiomyoma cells and decreases extracellular matrix-associated protein expression. Journal of Functional Foods 2016;23:241-252.

14 Zhang D, Al-Hendy M, Richard-Davis G, Montgomery-Rice V, Sharan C, Rajaratnam V, Khurana A, Al-Hendy A: Green tea extract inhibits proliferation of uterine leiomyoma cells in vitro and in nude mice. Am J Obstet Gynecol 2010;202:289.e1-9. 


\section{Cellular Physiology Cell Physiol Biochem 2018:49:1970-1986 and Biochemistry DOI: 10.1159/000493660 2018 (O) 2018 The Author(s). Published by S. Karger AG, Basel

15 Roshdy E, Rajaratnam V, Maitra S, Sabry M, Allah AS, Al-Hendy A: Treatment of symptomatic uterine fibroids with green tea extract: a pilot randomized controlled clinical study. Int J Womens Health 2013;5:477-486.

16 Islam MS, Giampieri F, Janjusevic M, Gasparrini M, Forbes-Hernandez TY, Mazzoni L, Greco S, Giannubilo SR, Ciavattini A, Mezzetti B, Capocasa F, Castellucci M, Battino M, Ciarmela P: An anthocyanin rich strawberry extract induces apoptosis and ROS while decreases glycolysis and fibrosis in human uterine leiomyoma cells. Oncotarget 2017;8:23575-23587.

17 Bilan MI, Grachev AA, Ustuzhanina NE, Shashkov AS, Nifantiev NE, Usov AI: Structure of a fucoidan from the brown seaweed Fucus evanescens C.Ag. Carbohydrate Research 2002;337:719-730.

18 Li B, Lu F, Wei X, Zhao R: Fucoidan: Structure and Bioactivity. Molecules 2008;13:1671-1695.

19 Cumashi A, Ushakova NA, Preobrazhenskaya ME, D’Incecco A, Piccoli A, Totani L, Tinari N, Morozevich GE, Berman AE, Bilan MI, Usov AI, Ustyuzhanina NE, Grachev AA, Sanderson CJ, Kelly M, Rabinovich GA, Iacobelli S, Nifantiev NE, Consorzio Interuniversitario Nazionale per la Bio-Oncologia I: A comparative study of the anti-inflammatory, anticoagulant, antiangiogenic, and antiadhesive activities of nine different fucoidans from brown seaweeds. Glycobiology 2007;17:541-552.

20 Ruperez P, Ahrazem 0, Leal JA: Potential antioxidant capacity of sulfated polysaccharides from the edible marine brown seaweed Fucus vesiculosus. J Agric Food Chem 2002;50:840-845.

21 Cho M, Lee DJ, Kim JK, You S: Molecular characterization and immunomodulatory activity of sulfated fucans from Agarum cribrosum. Carbohydr Polym 2014;113:507-514.

-22 Hwang PA, Hung YL, Chien SY: Inhibitory activity of Sargassum hemiphyllum sulfated polysaccharide in arachidonic acid-induced animal models of inflammation. J Food Drug Anal 2015;23:49-56.

23 Liu M, Liu Y, Cao MJ, Liu GM, Chen Q, Sun L, Chen H: Antibacterial activity and mechanisms of depolymerized fucoidans isolated from Laminaria japonica. Carbohydr Polym 2017;172:294-305.

24 Park MK, Jung U, Roh C: Fucoidan from marine brown algae inhibits lipid accumulation. Mar Drugs 2011;9:1359-1367.

25 Wu L, Sun J, Su X, Yu Q, Yu Q, Zhang P: A review about the development of fucoidan in antitumor activity: Progress and challenges. Carbohydr Polym 2016;154:96-111.

26 Wang CY, Wu TC, Hsieh SL, Tsai YH, Yeh CW, Huang CY: Antioxidant activity and growth inhibition of human colon cancer cells by crude and purified fucoidan preparations extracted from Sargassum cristaefolium. J Food Drug Anal 2015;23:766-777.

27 You S, Yang C, Lee H, Lee B-Y: Molecular characteristics of partially hydrolyzed fucoidans from sporophyll of Undaria Pinnatifida and their in vitro anticancer activity. Food Chemistry 2010;119:554-559.

28 Choi JI, Kim HJ: Preparation of low molecular weight fucoidan by gamma-irradiation and its anticancer activity. Carbohydr Polym 2013;97:358-362.

29 Cho TM, Kim WJ, Moon SK: AKT signaling is involved in fucoidan-induced inhibition of growth and migration of human bladder cancer cells. Food Chem Toxicol 2014;64:344-352.

-30 Lee YE, Kim H, Seo C, Park T, Lee KB, Yoo SY, Hong SC, Kim JT, Lee J: Marine polysaccharides: therapeutic efficacy and biomedical applications. Arch Pharm Res 2017;40:1006-1020.

-31 Lin CQ Singh J, Murata K, Itahana Y, Parrinello S, Liang SH, Gillett CE, Campisi J, Desprez PY: A role for Id-1 in the aggressive phenotype and steroid hormone response of human breast cancer cells. Cancer Res 2000;60:1332-1340.

-32 Sanjeewa KKA, Lee JS, Kim WS, Jeon YJ: The potential of brown-algae polysaccharides for the development of anticancer agents: An update on anticancer effects reported for fucoidan and laminaran. Carbohydr Polym 2017;177:451-459.

33 Vishchuk OS, Sun H, Wang Z, Ermakova SP, Xiao J, Lu T, Xue P, Zvyagintseva TN, Xiong H, Shao C, Yan W, Duan Q, Zhu F: PDZ-binding kinase/T-LAK cell-originated protein kinase is a target of the fucoidan from brown alga Fucus evanescens in the prevention of EGF-induced neoplastic cell transformation and colon cancer growth. Oncotarget 2016;7:18763-18773.

34 Yan MD, Yao CJ, Chow JM, Chang CL, Hwang PA, Chuang SE, Whang-Peng J, Lai GM: Fucoidan Elevates MicroRNA-29b to Regulate DNMT3B-MTSS1 Axis and Inhibit EMT in Human Hepatocellular Carcinoma Cells. Mar Drugs 2015;13:6099-6116.

-35 Zhang Z, Teruya K, Yoshida T, Eto H, Shirahata S: Fucoidan extract enhances the anti-cancer activity of chemotherapeutic agents in MDA-MB-231 and MCF-7 breast cancer cells. Mar Drugs 2013;11:81-98.

-36 Challen GA, Little MH: A side order of stem cells: the SP phenotype. Stem Cells 2006;24:3-12. 


\section{Cellular Physiology Cell Physiol Biochem 2018;49:1970-1986 \begin{tabular}{l|l|l|l|} 
and BoI: 10.1159/000493660 & 2018 The Author(s). Published by S. Karger AG, Basel \\
\hline
\end{tabular}

37 Rao KB, Malathi N, Narashiman S, Rajan ST: Evaluation of myofibroblasts by expression of alpha smooth muscle actin: a marker in fibrosis, dysplasia and carcinoma. J Clin Diagn Res 2014;8:ZC14-17.

-38 Holdsworth-Carson SJ, Zaitseva M, Vollenhoven BJ, Rogers PA: Clonality of smooth muscle and fibroblast cell populations isolated from human fibroid and myometrial tissues. Mol Hum Reprod 2014;20:250-259.

-39 Yan Z, Shen D, Liao J, Zhang Y, Chen Y, Shi G, Gao F: Hypoxia Suppresses TGF-B1-Induced Cardiac Myocyte Myofibroblast Transformation by Inhibiting Smad2/3 and Rhoa Signaling Pathways. Cell Physiol Biochem 2018;45:250-257.

40 Levy G, Malik M, Britten J, Gilden M, Segars J, Catherino WH: Liarozole inhibits transforming growth factorbeta3--mediated extracellular matrix formation in human three-dimensional leiomyoma cultures. Fertil Steril 2014;102:272-281 e272.

-41 Joseph DS, Malik M, Nurudeen S, Catherino WH: Myometrial cells undergo fibrotic transformation under the influence of transforming growth factor beta-3. Fertil Steril 2010;93:1500-1508.

$\$ 42$ Li Q: Transforming growth factor beta signaling in uterine development and function. J Anim Sci Biotechnol 2014;5:52.

43 Ciebiera M, Wlodarczyk M, Wrzosek M, Meczekalski B, Nowicka G, Lukaszuk K, Ciebiera M, SlabuszewskaJozwiak A, Jakiel G: Role of Transforming Growth Factor beta in Uterine Fibroid Biology. Int J Mol Sci 2017;18:pii:E2345.

44 Mas A, Cervello I, Gil-Sanchis C, Faus A, Ferro J, Pellicer A, Simon C: Identification and characterization of the human leiomyoma side population as putative tumor-initiating cells. Fertil Steril 2012;98:741-751.e6.

45 Sherr CJ: Cancer Cell Cycles. Science 1996;274:1672-1677.

-46 Kovacs KA, Oszter A, Gocze PM, Kornyei JL, Szabo I: Comparative analysis of cyclin D1 and oestrogen receptor (alpha and beta) levels in human leiomyoma and adjacent myometrium. Mol Hum Reprod 2001;7:1085-1091.

-47 Xue M, Ji X, Xue C, Liang H, Ge Y, He X, Zhang L, Bian K, Zhang L: Caspase-dependent and caspaseindependent induction of apoptosis in breast cancer by fucoidan via the PI3K/AKT/GSK3beta pathway in vivo and in vitro. Biomed Pharmacother 2017;94:898-908.

48 Hsu HY, Lin TY, Wu YC, Tsao SM, Hwang PA, Shih YW, Hsu J: Fucoidan inhibition of lung cancer in vivo and in vitro : role of the Smurf2-dependent ubiquitin proteasome pathway in TGFbeta receptor degradation. Oncotarget 2014;5:7870-7885.

49 Strzalka W, Ziemienowicz A: Proliferating cell nuclear antigen (PCNA): a key factor in DNA replication and cell cycle regulation. Ann Bot 2011;107:1127-1140.

50 Zhang YE: Non-Smad pathways in TGF-beta signaling. Cell Res 2009;19:128-139.

51 Nierth-Simpson EN, Martin MM, Chiang TC, Melnik LI, Rhodes LV, Muir SE, Burow ME, McLachlan JA: Human uterine smooth muscle and leiomyoma cells differ in their rapid 17beta-estradiol signaling: implications for proliferation. Endocrinology 2009;150:2436-2445.

52 He T, Bai X, Yang L, Fan L, Li Y, Su L, Gao J, Han S, Hu D: Loureirin B Inhibits Hypertrophic Scar Formation via Inhibition of the TGF-beta1-ERK/JNK Pathway. Cell Physiol Biochem 2015;37:666-676.

53 Tanwar PS, Lee HJ, Zhang L, Zukerberg LR, Taketo MM, Rueda BR, Teixeira JM: Constitutive activation of Beta-catenin in uterine stroma and smooth muscle leads to the development of mesenchymal tumors in mice. Biol Reprod 2009;81:545-552.

54 Ono M, Yin P, Navarro A, Moravek MB, Coon VJ, Druschitz SA, Gottardi CJ, Bulun SE: Inhibition of canonical WNT signaling attenuates human leiomyoma cell growth. Fertil Steril 2014;101:1441-1449.

55 Chong CC, Stump RJ, Lovicu FJ, McAvoy JW: TGFbeta promotes Wnt expression during cataract development. Exp Eye Res 2009;88:307-313.

56 Ota C, Baarsma HA, Wagner DE, Hilgendorff A, Königshoff M: Linking bronchopulmonary dysplasia to adult chronic lung diseases: role of WNT signaling. Mol Cell Pediatr 2016;3:34. 